\title{
Chlorine in the bleaching of pulp and paper
}

\author{
Keith R. Solomon \\ Centre for Toxicology, University of Guelph, Guelph ON N1G 2W1, Canada
}

\begin{abstract}
The pulp and paper industry in Canada contributes significant effluent discharges to surface and marine waters. Chlorine and chlorine compounds are used in the bleaching of pulp. A large number of organochlorine chemicals of widely differing properties are, or have been, produced from this bleaching. These range from the highly hydrophobic, persistent and bioaccumulative toxic substances, such as $2,3,7,8-\mathrm{TCDD}$, to the higher molecular weight, nonhydrophobic material usually characterized by absorbable organic halogen. Chlorine dioxide and chlorine react with lignin by different chemical processes and produce different organochlorine products. Use of molecular chlorine as a bleaching agent results in the formation and release of chlorinated organic compounds, sometimes at concentrations that present an unacceptable risk to the receiving environment and the food chain. Alternatives to the use of molecular chlorine, such as chlorine dioxide, result in reductions in the quantities of organochlorines produced, and the degree of chlorine substitution in the organochlorines formed. This, in turn, leads to reduced persistence, reduced potential for bioaccumulation and food chain transfer, reduced toxicity and reductions in adverse ecological effects. However, sufficient evidence exists from responses observed at non-bleached mills to show that other (probably non-halogenated) compounds are released or formed during the production of pulp and cause responses such as induction of MFOs, changes in hormone levels, and reproductive effects.
\end{abstract}

\section{INTRODUCTION}

From the Canadian perspective, the pulp and paper industry is important, both as an employer with about 250000 jobs in the industry and related services, as a contributor to the GNP (2.5\%), and for the release of effluents in what many perceive as a pristine environment [1].

Pulp production has two main objectives-to separate cellulose fibres from lignin with the minimum of physical damage to the fibres and to remove as much lignin from the fibres as possible. The best paper is produced from long fibres of the highest brightness. Fibres in pulp may be further treated to remove residual lignin and further brighten the resultant papers. This process results in the release of large amounts of material. Although significant technological advances have reduced emissions to the environment since the 1970s [1], estimated discharges of air pollutants in 1986 were 100000 tonnes of particulates, 80000 tonnes of sulphur dioxide 60000 tonnes of carbon monoxide, 15000 tonnes of nitrogen oxide, and 12000 tonnes of hydrocarbons [1]. These discharges appear to be widely dispersed into the atmosphere and have not been judged to be of major toxicological significance. About $80 \%$ of the pulp and paper mills in Canada discharge their water-borne effluents directly into surface or marine waters. These discharges have been categorised into total suspended solids (TSS), biological oxygen demand (BOD) and toxic discharge. This latter category is based on the proportion of failed acute lethality tests and the flow of discharge from the mill. Estimated annual direct discharges in relation to production from pulp mills in 1985 are shown in Table 1 [1].

From these numbers it is evident that a considerable amount of organic material (BOD) is released into the aquatic ecosystem from these mills. Much of this material is natural in origins but some is produced during the chemical reactions used in the mill. In the case of bleached kraft mills, some of this material consists of organochlorine compounds.

Intense debate continues about the use of chlorine and chlorine-containing products in the production of many chemical substances and in the production of pulp and paper [2]. This concern has lead to a viewpoint that the only effective response to organochlorine contamination in the environment and in the human food chain is to ban or restrict chlorine and chlorine compounds as industrial feedstocks [3]. In the 
Table 1 Discharges of effluents from Canadian pulp and paper mills in 1985

\begin{tabular}{ll}
\hline Parameter & Quantity \\
\hline Total production of pulp & 3400000 tonnes \\
Estimated toxic discharges & $5800000 \mathrm{~m}^{3}$ \\
Biological Oxygen Demand (BOD) & 730000 tonnes \\
Total Suspended Solids (TSS) & 347000 tonnes \\
\hline
\end{tabular}

area of pulp and paper production, this debate evolved from reports of the research conducted during the Swedish Environmental Cellulose I project [4] that focused concerns regarding pulp mill operations towards bleaching with chlorine and the environmental and toxicological effects of the products formed during that process.

Pulp is produced by a variety of methods that are usually grouped into mechanical or chemical

(sulphite or kraft) categories. To produce light coloured pulp products and papers, colourless cellulose fibres and coloured lignin are initially separated by chemical methods in which the lignin is depolymerized and dissolved. This is achieved via two processes, the sulphite process and the kraft (sulphate) process. The kraft process dominates because it produces stronger pulp than the mechanical processes and allows more efficient recovery of feedstock chemicals than the sulphite process, thus minimizing releases into the environment. However, the process of lignin removal is less efficient than the sulphite process and more bleaching of the pulp is required to produce bright papers. The kraft process results in the removal of about $55 \%$ of the original weight of the wood. These compounds, dissolved in the so-called black liquor, are removed by filtration, concentrated through evaporation and then burned to recover energy and the inorganic compounds for reuse.

\section{Bleaching of pulp}

For the production of bright papers and pulp products, fibres are further treated to remove residual lignin remaining after the kraft process. This process of bleaching (delignification and brightening) uses several chemicals and processes (Fig. 1, updated from [5]). A number of processes and variants of existing processes that increase the efficiency of the process for removal of lignin or offer substitutes for bleaching with molecular chlorine have been implemented in the industry (A and B, Fig. 1) and have been reviewed [6]. As has also been pointed out [6], classification of mills by their process technology results in an oversimplification of the nature and concentrations of the byproducts of the mills and chemicals released from the mill into the receiving environment dependent on several factors including: the species of wood used; the degree black liquor recovery in the mill; the presence of paper manufacture at the mill; the type of bleaching process; and the degree to which mill effluent is treated before being released. As a result of this, chemicals released from pulp mills are not similar from one mill to the other or over time at any particular mill, presenting a problem for scientific investigation [7]. Chlorine has traditionally been used as a bleaching agent because of its strong electrophilic or oxidizing properties, but, unfortunately, with these properties come characteristics that can have adverse effects in the environment. This paper will focus on these properties and mitigation of potential adverse effects through the use of other forms of chlorine for bleaching.

\section{REACTIONS IN THE BLEACHING PROCESS}

\section{The effects of chlorination}

A number of natural substances may become substituted with chlorine during the bleaching process. Substitution of organic compounds with chlorine reduces the reactivity of the resulting compound. This stability increases biological environmental persistence and this property further increases with increasing chlorination. Because of the large size and mass of the chlorine atom, substitution of $\mathrm{Cl}$ for $\mathrm{H}$ increases molar volume by about $21 \mathrm{~cm}^{3} / \mathrm{mol}$, equivalent to the effect of adding a methyl $\left(\mathrm{CH}_{3}\right)$ group [6]. This results in the formation of a larger molecule with reduced vapour pressure, an increased boiling point, and reduced solubility in water. This effect is incremental, becoming larger as additional chlorine atoms are added to the molecule and brings with it an increasing tendency to partition from water into organic phases, such as lipids in organisms. This results in an increasing tendency to bioconcentrate in organisms, which, in turn, results in higher concentrations in the body and greater toxicity. The incremental effects of increasing 


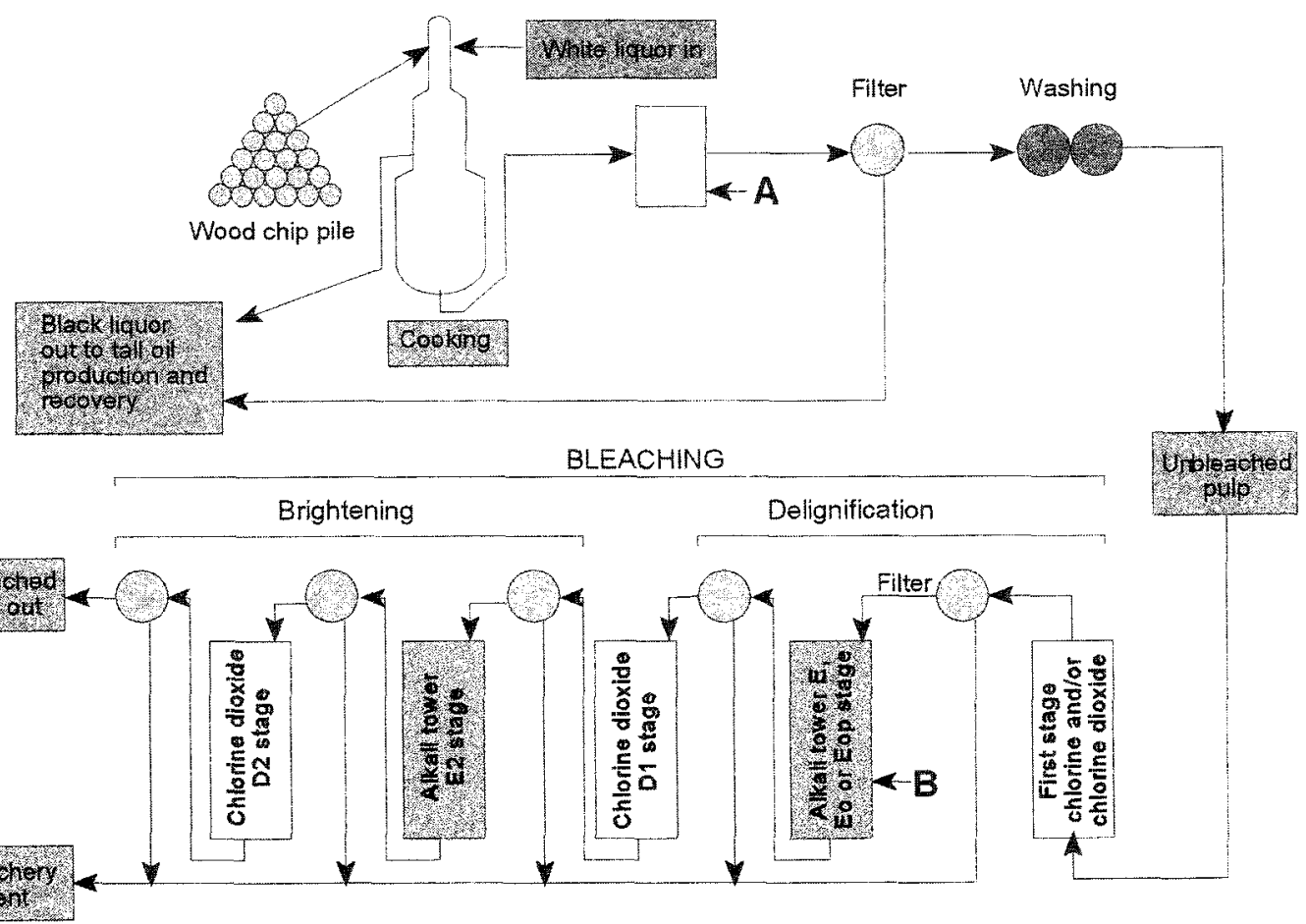

rig. I Arait pulp mill and bleaching process. (A) Uptional oxygen aeıınitication. (B) Optional oxygen and/or hydrogen peroxide bleaching stage.

substitution are fundamental to the understanding that the ecologically important properties of chlorinated substances chemical will vary with the number of chlorine atoms in the molecule and that the resulting effects on toxicity, environmental transport, and transformation are generally understood and predictable [6].

Of the organochlorine compounds produced in the bleaching of pulp, those of greatest concern are persistent, highly bioaccumulative, and toxic. These properties are similar to those of other persistent organic pollutants such as the chlorinated biphenyls (PCBs), dioxins (PCDDs), dibenzofurans (PCDFs), chlorinated benzenes, and pesticides such as DDT [8] and represent a relatively rare combination of characteristics that result in higher risks to the environment (Fig. 2). The formation of these compounds is the result of the nature of the reactions in the bleaching process and use of molecular chlorine. These reactions are discussed in the next section.

\section{Chlorination reactions in the bleaching of pulp}

At this time, the majority of bleaching processes rely on the use of molecular chlorine and chlorine dioxide as the oxidizing agent to remove residual lignin from the cellulose fibres. Traditionally, molecular chlorine, with a small percentage $(10 \%)$ of chlorine dioxide was favoured. However, more recently, mills have switched to $100 \%$ substitution of molecular chlorine with chlorine dioxide. This change in the industry has been driven by the need to reduce both the amount and the degree of chlorinated compounds released from the bleaching process. The reasons for the shift to chlorine dioxide technology are found in the chlorination reactions that occur in the bleaching process and the extent to which these contribute to the formation of potentially hazardous byproducts.

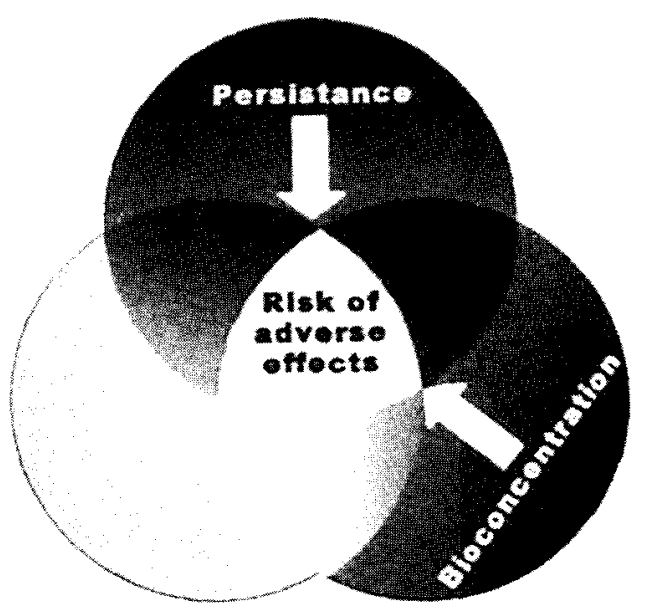

Fig. 2 Illustration of the combination of properties which, in organochlorine compounds, will result in adverse effects. 
Molecular chlorine

A

B

C

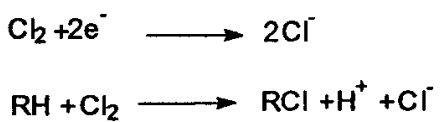

(ln

D

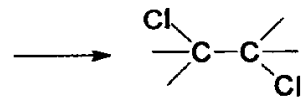

Dichloro compound

\section{Chlorine dioxide}
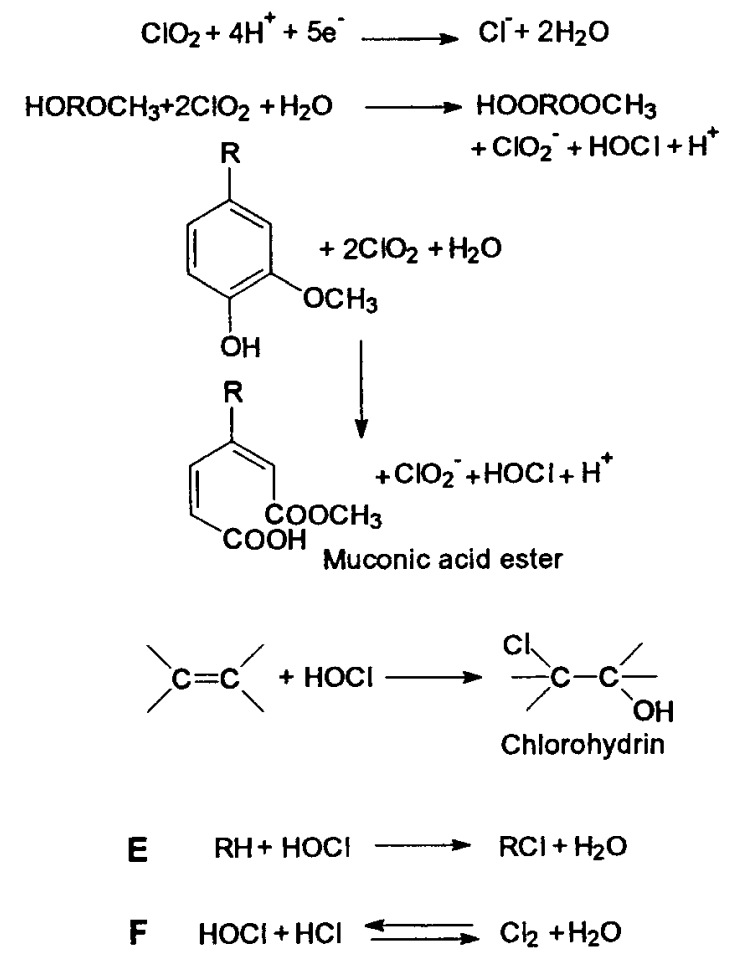

Fig. 3 The reactions of molecular chlorine and chlorine dioxide during the bleaching process.

The oxidation level of the chlorine atom in chlorine dioxide $\left(\mathrm{ClO}_{2}\right)$ is +4 , while in molecular chlorine $(\mathrm{Cl} 2)$ the oxidation level of the chlorine atom is +1 (Fig. 3A). After reduction to chloride ion (oxidation level -1 ), there is a change of five oxidation levels in the case of chlorine dioxide and two oxidation levels in the case of molecular chlorine. Chlorine dioxide thus has 5 times the oxidation potential of molecular chlorine per chlorine atom and is therefore a much stronger oxidant.

In addition to acting as an oxidizing agent, chlorine acts as a chlorinating agent (Fig. 3B). In the first stage of bleaching (Fig. 1), about half the chlorine applied to pulp combines with the lignin and the remainder oxidizes the lignin and is converted to chloride ion (Fig. 3B and C) [9]. After alkaline extraction (Fig. 1), about $90 \%$ of the original chlorine applied to pulp is converted to chloride ion but $10 \%$ remains as chlorinated organic compounds. Chlorine also reacts with double bonds to produce dichlorinated products (Fig. 3D) which are stable in subsequent alkali washing (Fig. 2).

Chlorine dioxide reacts differently with lignin. In the oxidation of lignin, muconic acid esters (Fig. 3B and C) are formed [10] and chlorine dioxide is reduced to chlorite ion and hypochlorous acid. Chlorite ions decompose in the acid medium to reform chlorine dioxide and chloride ions or they react with the hypochlorous acid to form chlorate ions [11]. Hypochlorous acid may react with organic material to form chlorinated organic compounds. This reaction may be direct or it may involve the formation of chlorine which can exist in equilibrium with hypochlorous acid (Fig. 3F). However, this equilibrium state is strongly $\mathrm{pH}$ dependent [6]. At $\mathrm{pH}<2$, the chlorine species is primarily present as dissolved $\mathrm{Cl}_{2}$. At near-neutral conditions ( $\mathrm{pH} \mathrm{5)}$ the dominant species is $\mathrm{HOCl}$ and, under alkaline conditions, the hypochlorous acid dissociates to hypochlorite ions $\left(\mathrm{OCl}^{-}\right)$. By the use of $\mathrm{pH}$ manipulation in chlorine dioxide bleaching, the formation of chlorine can be controlled and fewer chlorinated compounds are produced [12]. Compared to molecular chlorine, hypochlorous acid reacts differently with the chemical structures present in lignin, producing, for example, chlorohydrins (Fig. 3D). This chlorine is more easily eliminated from chlorohydrins during subsequent alkaline stages of bleaching (Fig. 2) than from the dichlorinated products produced from reactions with chlorine and less chlorinated organic material is ultimately formed. As a result of a combination of the strong oxidizing capability of $\mathrm{ClO}_{2}$, a reduction in the extent of chlorination and the oxidative changes in lignin there is a five to ten-fold reduction in the formation of organochlorine compounds when $\mathrm{ClO}_{2}$ is substituted for $\mathrm{Cl}_{2}[6]$. 


\section{Changes in production of chlorinated compounds in mill effluent}

As a result of changes in the underlying chemistry of bleaching, there is a change in both the amounts and the nature of the of the chlorinated products formed as chlorine is increasingly substituted for chlorine dioxide (Fig. 4). The amounts of absorbable (AOX) and extractable organic halogen (EOX) decrease to lower levels when high substitution of chlorine dioxide is used. a more recent survey of similar changes in Swedish mills [13] showed similar decreases in AOX from $2.9 \mathrm{~kg} /$ tonne pulp to 0.19 and $0.01 \mathrm{~kg} /$ tonne pulp when chlorine dioxide substitution was changed from 8 to $100 \%$. In similar vein, total chlorophenols decrease with increasing chlorine dioxide substitution. In addition, a shift occurs in the ratio of high to low substituted chlorophenols. Mono- and di-substituted chlorophenols decreased from 2.4-7.4 g/tonne pulp to 0.16$0.09 \mathrm{~g} /$ tonne pulp, while tri- and tetra-chlorophenols decreased from $10.6-23$ and 0.3 to $2.8 \mathrm{~g} /$ tonne pulp respectively to below the level of detection [13]. Similar decreases in chlorinated acetic acids and chloroform have been observed [13]. Polychlorinated dioxins and dibenzofurans (PCDD/PCDFs) are also reduced to at or below the level of detection $[6,13]$ in mills using $100 \%$ chlorine dioxide substitution.

While much attention has been focussed in the use of elemental chlorine free (ECF) bleaching processes as a means of eliminating discharge of chlorinated compounds into the environment, effluents from mills using ECF are not free of chlorinated compounds. Strömberg et al. [13] showed that concentrations of chlorinated phenols, chlorinated acetic acids, chloroform and PCDD/PCDFs could be detected in mills using no chlorine at all in the bleaching process. These concentrations were close to background but were, in fact, similar to those detected in mills using $100 \%$ chlorine dioxide substitution. AOX concentrations were, however, $0.01 \mathrm{~kg} /$ tonne pulp or less in some ECF mills and thus somewhat lower than in mills using chlorine dioxide bleaching.

\section{Effects of effluent treatment on compounds released from pulp mills}

Most pulp in North America have some form of treatment of bleached kraft mill effluent by processes such as activated sludge and aerated stabilization basins or lagoons. Removal efficiencies have been determined for AOX, chlorophenols, chloroform, and hydrophobic compounds, such as the dioxins (summarized in [6]). In general, hydrophobic organics partition strongly to biomass and are removed by sedimentation with possible subsequent mineralization by aerobic or anaerobic processes. The unmineralized portion may be retained in sludges and their ultimate fate is determined by sludge management practices. Chlorophenolics are substantially biodegraded in aerated lagoons, with typical removals in activated sludge range from $50 \%$ to $90 \%$. Compounds with lower chlorine substitution are more easily degraded. AOX is typically removed with about $50 \%$ efficiency, probably by settling and subsequent degradation and/or mineralization in the sludge. The efficiency of removal has recently been reviewed by LaFleur [14] and his data are summarized in Fig. 5.

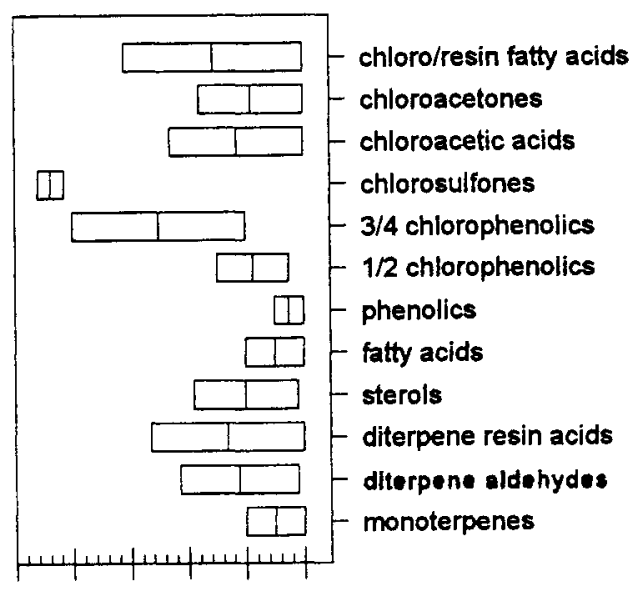

$02040 \quad 60 \quad 80100$

Percent removal

Fig. 5 Range of treatment efficiencies for various groups of compounds in pulp mill effluent (redrawn from data in [5]). 
Body burdens of a number of organochlorines have been used as an indicator of reduction in the release of bioaccumulative organochlorine compounds from pulp and paper mills. When measured in a study on the Grande Prairie ecosystem in relation to process change to $100 \%$ chlorine dioxide bleaching [15]. Hydrophobic organochlorines such as $2,3,7,8-\mathrm{TCDD} / \mathrm{TCDF}$ were found in sediments, in benthic organisms and in fish. Levels appeared to be related to feeding habit with higher concentrations in whitefish (which feed on benthic filter feeders). After implementation of $100 \%$ chlorine dioxide bleaching, levels of $2,3,7,8-$ TCDD/TCDF in sediments declined rapidly but levels in fish persisted. Levels of EOCl declined after the change to $100 \%$ chlorine dioxide, suggesting that the compounds measured as EOX were more rapidly excreted than dioxins. These data support the conclusion that $100 \%$ substitution with chlorine dioxide results in significant reductions in the production as well as the uptake of bioaccumulative organochlorines from pulp mill effluents. Subsequent follow-up showed reductions in fish to levels near those of reference sites [16].

\section{TOXICOLOGICAL RELEVANCE OF CHLORINATED AND OTHER SUBSTANCES RELEASED FROM PULP MILLS}

\section{Biomarkers and bioindicators of exposure and effects}

For chemicals that bioaccumulate, such as the dioxins and dibenzofurans, body burdens can be used to characterize exposure. However, if the exposed organisms are not constrained to the receiving environment, exposure may not have occurred where the animal was found. Even if a compound is found in an organism, the relevance of this to the physiology of the organisms is difficult to determine in the absence of a thorough understanding of the toxicology of the compound. This has led to the development of a suite of biochemical, physiological and histological assays to allow the organism itself to provide information as to whether or not exposure or responses have occurred. These responses are biomarkers or bioindicators, and for some may be indicative an adverse biological effects. Unfortunately, the linkage between exposure and resulting adverse effects, as measured by biomarkers and bioindicators, is unclear for most of the assays currently in use [6].

Ideally biomarkers should be predictive of adverse effects (respond at lower concentrations or at an earlier time than the adverse effect becomes manifest). To be useful as measurement endpoints, they should also be mechanistically and biologically linked to assessment endpoints that have ecological or societal value [17]. Many responses measured by biomarker assays are merely adaptive phenomena and, because they occur in the normal range of adaptation, result in no harm to the organism.

\section{Inducers of mixed function oxidases}

The biomarker that has been most used, relative to bleached kraft mill effluents, involves induction of a family of enzymes called the P450 system (MFO). In aquatic and many other organisms, these enzymes convert endogenous and exogenous hydrophobic substances to more polar metabolites thus making them more water soluble, usually less toxic, and more easily excreted. In fish, cytochrome P4501 A, responds to exposure to some chlorinated aromatic compounds as well as some aromatic hydrocarbon and is induced in the liver and other organs. Elevated levels of P4501A, usually measured as induction of ethoxyresorufinO-deethylase (EROD) in fish livers from a receiving environment, indicates exposure to inducing chemicals [18]. Induction of these enzymes could be detrimental in several ways, such as, for example, the metabolism of endogenous chemicals necessary for the health of the species [19].

Induction of mixed function oxidase enzymes has been reported in fish from waters receiving effluent from mills using chlorine and from those not using chlorine [20,21 and reviewed in 22 and 23]. Induction is correlated with exposure to effluent and with other responses such as reproductive function and population characteristics [22]. Induction has also been shown to be rapidly provoked and to dissipate rapidly in response to changes in effluent flow [24]. However, these responses are not necessarily linked to adverse effects. The results of early lifestage tests in fathead minnows and Ceriodaphnia dubia showed no correlation with EROD induction in white sucker [20] nor with responses in serum steroids or type of mill and bleaching process $[19,23]$. The EROD inducer appears to be rapidly cleared from the fish [24] but may be persistent and associated with sediments and the sediment-dwelling food chain [25]. The finding that pulp 
mill effluent from mills that use $100 \%$ chlorine dioxide substitution or no chlorine at all will induce EROD suggests that the substance responsible is not chlorinated, or, at least, not highly chlorinated like the dioxins and furans or the higher chlorinated phenolics. It has been suggested [22] that the MFO inducer is a PAH or has a PAH-type structure and similar chemical and biological properties.

\section{Reproductive and endocrine effects}

It is widely recognized that fish in pulp mill receiving waters show a number of reproductive and endocrine responses including changes in plasma steroid levels in fish [19,24,26,27]. Although it was originally assumed that organochlorines were principally responsible for MFO and plasma steroid responses in fish exposed to pulp mill effluents, results from a number of recent studies have shown MFO induction caused by effluents from both bleached and unbleached mills $[19,20,28]$. This suggests that the chemical(s) responsible for this induction probably originate in the pulping process prior to the bleaching stage and are unlikely to be chlorinated materials formed in the bleaching process. Laboratory studies have shown that some of the responses reported from the field (delayed maturation and reduced gonadal:somatic indices (GSIs) can also be observed in fathead minnows exposed to effluents from egg to adult as can changes in steroid levels in male fish [29]. Laboratory trials with goldfish as the test organism exposed to pulp mill effluent have been conducted [30] and similar trends of steroid depression to those in wild fish in receiving waters at Jackfish Bay, Kapuskasing and Smooth Rock Falls (Canada) have been seen. Sterols from plants (phytosterols) have been found in mill effluents and have been shown to produce steroid hormone depressions in fish [31], however, further tests on specific compounds found in pulp mill effluent have failed to identify compounds of high activity.

\section{OBSERVATIONS FROM THE FIELD}

For pulp mill receiving waters, a relatively large body of historical information on the effects of effluents produced from older technology is available. Where pre-exposure populations have been studied, the shifts in populations appeared to be related to changes in the availability of food or to differences in food type [7]. Zooplankton found near mill discharges in the Lake Keurusselkä receiving water tended to be detrital (bacterial) feeders, whereas those at more remote sites were phytoplankton feeders, reflecting the greater availability of detrital matter in the discharges [32]. Similar, organic-loading-dependent, responses have been reported in other sites such as Nipigon Bay in Lake Superior, the Sacramento River and the Flint River [7]. In surveys of the Baltic conducted from the early 1970s, Landner et al. [33] showed that impacts on benthic macrofauna resulted from several sources of industrial pollution. Most of the responses that they reported appeared to be related more to habitat alteration than to specific toxic effects. Effects on habitat at pulp mill sites resulted from deposition of fibres on the bottom substrate and anoxic conditions in the sediments.

The Swedish 'Environment/Cellulose' project examined the biological/ecological, pathological and physiological impacts of primary treated bleached kraft mill effluent (BKME) discharged from a mill at Norrsundet on the fish community of the Gulf of Bothnia [34,35]. The early Norrsundet studies showed that benthic flora and fauna were affected in relation to the distance from the discharge [36]. Species diversity (number of species) of plants increased from 8 about $2 \mathrm{~km}$ from the discharge to $20,4.5 \mathrm{~km}$ from the site [36]. Invertebrates appeared to be less affected; 10 species were found $2 \mathrm{~km}$ from the discharge, rising to 13 at $4 \mathrm{~km}$. Numbers of species further from the sites showed variability but no consistent trend. Effects close to the outlet appeared to be most affected by the fibres settling to the bottom, covering suitable attachment sites and providing anoxic conditions [37,38]. Beyond the fibre mats, changes in distribution and population densities in aquatic algae were assessed to be caused by changes in nutrient levels, reduced light penetration and the toxic effects of chlorate on the brown alga Fucus vesiculosus. Invertebrate biomass was related to plant biomass, presumably in response to provision of habitat. Pollution tolerant species, such as chironomids, were present in the sampling stations closest to the discharge [37].

Fish populations were also affected. Density and diversity of the fish community were very low in areas less than $2 \mathrm{~km}$ from the discharge [4,39]. At sites $2 \mathrm{~km}$ to $4.5 \mathrm{~km}$ from the discharge, density of both adults and fry of roach (Rutilus rutilus) and ruffe (Gymnocephalus cernua) increased dramatically, an effect which was attributed to eutrophication by the effluent. In contrast, the abundance of adult and pelagic fry 
of perch (Perca fluviatilis L.), sand-goby (Pomatoschistus minutus [Pallas]) and herring (Clupea harengus) were low at the $2 \mathrm{~km}$ and $4.5 \mathrm{~km}$ sites, increasing in abundance at sites further from the discharge. The reductions in perch numbers were linked to larval mortality in followup studies [40,41]. Studies on gillnetted Rutilus rutilus, Gymnocephalus cernua and Perca fluviatilis at nine pulpmill sites in the Baltic (Karlsborg, Piteä, Husum, Örnskoldsvik, Köpmanholnen, Östrand, Ortviken, Sandarne and Norrsundet) showed similar population responses (increases in adult populations), regardless of the mill type (sulfite, non-bleached kraft or bleached kraft) [42]. These were apparently related to eutrophication of the receiving environment [43]. Similar effects were found in fish populations (Rutilus rutilus, Gymnocephalus cernua, Perca fluviatilis, Abramis brama at several pulp mill sites in the Baltic (Husum, Iggesund, Norrsundet, Korsnås and Mönsterås) [43]. Changes in populations of adult fish were ascribed to eutrophication effects but the authors suggested that reductions in abundance of fry were the result of toxic components in effluents. Predation upon fry by the large numbers of adult fish in these areas was not apparently considered by the authors as a possible explanation, nor were stomach contents in the ruffe and roach used to test this hypothesis. Studies in other environments have reported similar findings to the above. Hall et al. [44] showed reduced periphytic production in large outdoor stream mesocosms treated with high levels ( $5 \%$ dilution of effluent) of bleached kraft mill effluent. Stimulation was observed at lower concentrations, suggesting that the effects were a balance between effects of light penetration and the effects of nutrients in the effluents. Similar responses were noted in the macroinvertebrate community. Studies on white sucker (Catostomus commersoni) in Jackfish Bay of Lake Superior compared the stomach contents of fish from an area receiving bleached kraft mill effluent (primary treatment only, low chlorine dioxide substitution) to an uncontaminated control area. Number of organisms per gut and number of taxa were reduced at the site impacted by effluent. In as much as gut contents are an indicator of the community, this observation suggested community impacts. Fish populations in Jackfish Bay showed differences in their condition factors and a number of other physiological and biochemical indicators [45].

From this information, it is clear that physical, organic and nutrient components of the discharges from pulp mills have been the major source of population shifts and community effects in the past. These effects continue to occur in environments where turnovers or dilution rates in the receiving waters are low and nutrient controls are not implemented in the effluent treatment process. These impacts can mask and confound toxicity-mediated effects and hazard assessment must take this into consideration. The isolation of specific process-related effects at the population level from this web of causality is difficult and has not been carried out in the field studies conducted to date.

\section{CONCLUSIONS}

On the basis of the evidence from studies on the use of chlorine and chlorine dioxide in the bleaching of pulp and paper, it is clear that the use of molecular chlorine as a bleaching agent results in the formation and release of chlorinated organic compounds, sometimes at concentrations that present an unacceptable risk to the receiving environment and the food chain. Alternatives to the use of molecular chlorine, such as chlorine dioxide, result in reductions in the quantities of organochlorines produced, and the degree of chlorine substitution in the organochlorines formed. This, in turn, leads to reduced persistence, reduced potential for bioaccumulation and food chain transfer, reduced toxicity and reductions in adverse ecological effects. However, sufficient evidence exists from responses observed at non-bleached mills to show that other, probably non-halogenated, compounds are released or formed during the production of pulp and cause responses such as induction of MFOs, changes in hormone levels, and reproductive effects. Improvements in mill technology and effluent treatment in recent decades have, in a sense, peeled the onion of environmental effects of pulp mills. Reductions in acute toxicity revealed the bioaccumulation and effects of chlorinated compounds and conversions to bleaching practices that make use of chlorine dioxide and other alternatives to molecular chlorine have revealed the potential effects of compounds of natural origins. It is clear that these compounds cause responses in both the MFO system and reproduction. The MFO response is most likely an indicator of exposure rather than adverse effects but the effects on reproduction remain to be characterized in terms of their relevance to assessment endpoints at the population and community level. The identification of the substances causing these responses and the elucidation of their mechanisms of action is a current research priority and should remain so. 


\section{REFERENCES}

1 W.F. Sinclair. Controlling pollution from Canadian pulp and paper manufacturers: A federal perspective. Environment Canada, Ottawa, xvii +360 pp. (1990).

2 I. Amato. Science 261, 152-154 (1993).

3 IJC. Persistent Toxic Substances: Virtually Eliminating Inputs to the Great Lakes. Interim Report of the Virtual Elimination Task Force. International Joint Commission, Windsor, Ontario, July 1992, 42 pp.

4 A. Södergren, B-E. Bengtsson, P. Jonsson, S. Lagergren, A. Larson, M. Olsson, L. Renberg. Water Sci. Technol. 20, 49-60 (1988).

5 K.P. Kringstad, K. Lindström. Env. Sci. Technol. 18, 236A-247A (1984).

6 K. Solomon, H. Bergman, R. Huggett, D. Mackay, B. McKague. A Review and Assessment of the Ecological Risks Associated with the Use of Chlorine Dioxide for the Bleaching of Pulp. Association for Environmental Technology, Erin ON. (1993) pp 73.

7 J.W. Owens. Env. Tox. Chem. 10, 1511-1540 (1991).

8 L. Ritter, K.R. Solomon, J. Forget, M. Stemeroff, C.O'Leary. Persistent organic pollutants: An assessment report on aldrin, chlordane, DDT, dieldrin, dioxins and furans, endrin, heptachlor, hexachlorobenzene, mirex, polychlorinated biphenyls, and toxaphene. IPCS Interorganization Programme for the Sound Management of Chemicals. UNEP, ILO, FAO, UNIDO and OECD. November 1995.

9 H.L. Hardell, F. de Sousa. Svensk Papperstidn. 80, 110-120, (1977).

10 J. Gierer. Wood Sci. Technol. 20, 1-33 (1986).

11 Y. Ni, G.J. Kubes, A.R.P. van Heiningen. Nordic Pulp Paper Res. J. 7, 200-204 (1992).

12 R.G. Hise, R.C. Streisel, A.M. Bills. Proceedings of the TAPPI Environmental Conference, Richmond VA., pp 1135-1142, (1992).

13 L. Strömberg, R. Mörck, F. de Souza, O. Dahlman. In Environmental Fate and Effects Of Pulp and Paper Mill Effluents (M.R. Servos, K.R. Munkittrick, J.H. Carey, G. Van der Kraak environmental disrupting substance.), pp. 3-19 St Lucie Press Delray Beach, FL (1996).

14 L.E. LaFleur. In Environmental Fate and Effects OfPulp and Paper Mill Effluents (M.R. Servos, K.R. Munkittrick, J.H. Carey, G. Van der Kraak environmental disrupting substance.), pp. 21-31, St Lucie Press Delray Beach, FL (1996).

15 S.M. Swanson, R. Schryer, R. Shelast, K. Holley, I. Berbekar, P.J. Kloepper-Sams, J.W. Owens, L. Steves, D. Birkholz, T. Marchant. Wapiti/Smokey River Ecosystem Study. Weyerhaeuser Canada, Grande Prairie, Alberta xxii +176 pp, (1993).

16 K.R. Solomon, H. Bergman, D. Mackay, B. McKague. A review and assessment of the ecological risks associated with the use of chlorine dioxide for the bleaching of pulp. In Proceedings of the 1994 International Pulp Bleaching Conference, Vancouver, June 13-16, 1994. Canadian Pulp and Paper Association, Montreal, PQ, (1994).

17 U.S. Environmental Protection Agency. Framework for Ecological Risk Assessment. Risk Assessment Forum, Washington, DC, EPA/630/R92/001.pp 41, (1992).

18 J.J. Stegeman, M. Brouwer, R.T. Di Giulio, L. Förlin, B. Fowler, B.M. Sanders, P.A. Van Veld. In: Blomarkers: Biochemical, Physiological and Histological Markers of Anthropogenic Stress. (R. Huggett, R. Kimerle, P. Mehrle, H. Bergman, Environmental disrupting substance.) Lewis Publishers, Boca Raton, Florida, 247 pp.

19 T. Andersson, L. Förlin, J. Härdig, Ȧ. Larsson. Mar. Env. Res. 24, 233-236 (1988).

20 R.D. Robinson, J.H. Carey, K.R. Solomon I.R. Smith, M.R. Servos, K.R. Munkittrick. Env. Tox. Chem. 13, 1075-1088 (1994).

21 K.R. Munkittrick, G.J. Van der Kraak, M.E. McMaster, C.B. Port, M.R. van den Heuvel, M.R. Servos. Env. Tox. Chem. 13, 1089-1101 (1994).

22 P. Hodson. In Environmental Fate and Effects Of Pulp and Paper Mill Effluents (M.R. Servos, K.R. Munkittrick, J.H. Carey, G. Van der Kraak environmental disrupting substance.), pp. 349-358, St Lucie Press Delray Beach, FL (1996).

23 K-L Lehtinen. In Environmental Fate and Effects Of Pulp and Paper Mill Effluents (M.R. Servos, K.R. Munkittrick, J.H. Carey, G. Van der Kraak environmental disrupting substance.), pp. 359-368, St Lucie Press Delray Beach, FL (1996).

24 K.R. Munkittrick, G.J. Van der Kraak, M.E. McMaster, C.B. Port. Env. Tox. Chem. 11, 1427-1439 (1992).

25 M.R. Servos, S.Y. Huestis, D.M. Whittle, G.J. Van der Kraak, K.R. Munkittrick. Eiv. Tox. Chem. 13, 1103-1116 (1994).

26 K.R. Munkittrick, C.B. Portt, G.J. Van der Kraak, I.R. Smith, D.A. Rokosh. Can. J. Fish. Aquat. Sci. 48, 1371$1380(1991)$.

27 K.R. Munkittrick, M.E. McMaster, C.B. Portt., G.J. Van der Kraak, I.R. Smith, D.G. Dixon. Can. J. Fish. Aquat. Sci. 49, 1560-1569 (1992). 
28 P. Lindström-Seppä, S. Huuskonen, M. Pesonen, P. Muona, O. Hänninen. Mar. Env. Res. 34, 157-161 (1992).

29 R. Robinson. Endocrine effects of pulp mill effluents on non-target aquatic organisms. PhD thesis. University of Guelph, (1994).

30 G.L. Van Der Kraak, M. McMaster. University of Guelph, Personal communication (1996).

31 G.L. Van Der Kraak, University of Guelph, personal communication (1996).

32 P. Eloranta. Ann. Zool. Fennici. 17, 261-267 (1988).

33 L. Landner, K. Nillson, R. Rosenberg. Vatten 3, 324-379 (1977).

34 T. Andersson, B-E. Bengtsson, L. Förlin, J. Härdig, A. Larsson. Ecotox. Env. Safety, 13, 53-60 (1987).

35 T. Andersson, L. Förlin, J. Härdig, Å. Larsson. Can. J. Fish. Aquat. Sci. 45, 1525-1536 (1988).

36 A. Södergren, B-E. Bengtsson, P. Jonsson, S. Lagergren, A. Larson, M. Olsson, L. Renberg. Water Sci. Technol. 20, 49-60 (1988).

37 H. Kautsky, U. Kautsky, S. Nellbring. Ophelia, 28, 139-155 (1988).

38 H. Kautsky, Ambio, 21, 308-313 (1992).

39 E. Neuman, and P. Karås. Water Sci. Technol. 20, 95-106 (1988).

40 O. Sandström, G. Thoresson. Mar. Pol. Bull. 19, 564-567 (1988).

41 P. Kåras, E. Neuman, O. Sandström. Can. J. Fish. Aquat. Sci. 48, 28-34 (1991).

42 S. Hansson. Ambio, 16, 344-348 (1987).

43 O. Sandström, P. Karås, E. Neuman. Finnish Fish. Res. 12, 101-110 (1991).

44 T.J. Hall, R.K. Haley, L.E. LaFleur. Env. Toxicol. Chem. 10, 1051-1060 (1991).

45 M.E. McMaster, M.E., G.J. Van der Kraak, C.B. Port, K.R. Munkittrick, P.K. Sibley, I.R. Smith, D.G. Dixon. Aquat. Toxicol. 21, 199-219 (1991). 